\title{
Comparison of the chemical constituents and in-vitro antibacterial efficacies of the extracts of Croton zambesicus Muell ARG. stem-bark
}

\author{
K. D. Reuben ${ }^{1}$, F. I. Abdulrahman ${ }^{2}$, J. C. Akan ${ }^{2 \star}$ and S. B. Aji \\ ${ }^{1}$ Department of Basic Sciences, Adamawa State College of Agriculture, Ganye, Nigeria. \\ ${ }^{2}$ Department of Chemistry, University of Maiduguri, Maiduguri, Nigeria. \\ ${ }^{3}$ Department of Animal Health and Production Technology, Adamawa State College of Agriculture, Ganye, Nigeria.
}

Accepted 9 September, 2010

\begin{abstract}
The stem bark of Croton zambesicus was extracted using soxlet apparatus with petroleum ether, ethyl acetate, methanol and distilled water respectively. The extracts were screened for chemical components. The results revealed the presence of carbohydrates, saponins, cardiac glycosides, flavonoides, terpenes/steroids and alkaloids. In vitro antimicrobial study of the extracts revealed strong broad spectrum activity, especially for methanol extract. This is evident from the minimum inhibitory concentration (MIC) and minimum bactericidal concentration (MBC) test results in which the methanol extract had MIC and MBC of $1.560 \mathrm{mg}$ on Staphylococcus aureus and Escherichia coli, followed by ethyl acetate extract with MIC value of $3.125 \mathrm{mg}$ and $6.25 \mathrm{mg}$ for MBC on Pseudomonas aeruginosa. Petroleum ether extract showed the highest activity on Shigella dysenteriae, S. aureus and E. coli with MIC value $25 \mathrm{mg}$ and $50 \mathrm{mg}$ for MBC while the aqueous extract did not show activity at all. The result of this study provide more basis and credence for the use of this plant in the treatment of ailments whose causative agents are some of the pathogenic microbes used in this study, and thus suggest the possible usefulness of $C$. zambesicus in the treatment of bacterial and fungal infections.
\end{abstract}

Key words: Croton zambesicus, chemical constituents, antimicrobial, efficacies, extracts.

\section{INTRODUCTION}

The history of the use of herbal medicine may be as old as the history of man kind. Thus the use of plants as medicine is an ancient practice common to all societies especially the African society (Usman and Osuji, 2007). Despite the level of world's development, the traditional medicinal methods, especially the use of medicinal plants still play a major role in the developing countries of Africa south of the Sahara and more so, the use of herbal remedy have risen in developed countries in the last decades (Kianbakht and Jahaniani, 2003; Usman et al., 2007).

Medicinal plants have been used for traditional treatment of numerous diseases in many parts of the world and in rural areas; they continue to be used as the

*Corresponding author. E-mail: joechemakan@yahoo.com. Tel: +2348036000506 . primary source of medicine (Chitme et al., 2003; Enzo, 2006). Over $80 \%$ of the world's population still use plants as their primary source of medicine (Codell, 2000; Kim, 2005) and in Africa particularly in Nigeria, herbal medicine has become part of the people's culture with about $70 \%$ depending mainly on traditional medication (Akiniyi and Tella, 1991; Osuinde and Isibor, 1998; Ajoku et al., 2001; Afawodi, 2001; Bauso and Olutimayin, 2001; Geidam et al., 2007). This over dependence is due to high cost of conventional primary health service (Geidam, 2007).

Croton zambesicus muell Arg. is of the Croton linn and a member of Euphorbiaceae family (Arbonnier, 2004). It is known as Koriba or Icen maser in Hausa, Ajekofola in Yoruba, Mfam in Ekoi (Agishi and Shehu, 2004; Arbonnier, 2004) and Moramora in Kilba language (Reuben et al., 2008; 2009a; 2009b; 2009c). Watt and Breyer-Brandwikj, (1962), Adjanohoun et al. (1989) and Okokon et al. (2005) have reported that the decoction 
from the leaves and stem-bark of $C$. zambesicus have been used in folk medicine as anti-hypertensive, antimicrobial (in urinary infection) and treatment of malaria. Other medicinal uses as reported by Abbiw (1990) and Arbonnier, (2004) include smoke of burnt leaf for convulsions due to fits and epilepsy, leaf decoction for diarrhea, dysentery, headaches, measles, high blood pressure, intestinal worms and roots as laxatives.

The aim of the present study is to identify the chemical constituents of the various extracts of $C$. zambesicus and to compare the in vitro anti-bacterial efficacies of the extracts against some bacterial organisms with the view of providing validity for its reported folkloric medicinal uses.

\section{MATERIALS AND METHODS}

\section{Sample collection and identification}

The stem-bark of $C$. zambesicus Muell Arg. was collected in Mubi, Adamawa State, Nigeria. The stem-bark of $C$. zambesicus was authenticated by Prof. S. S. Sanusi and voucher specimen with No. $19052001 / 2$ was deposited at the Department of Biological Sciences, University of Maiduguri, Maiduguri, Nigeria.

\section{Preparation and extraction of plant material}

The collected stem-bark of $C$. zambesicus was pulverized using wooden pestle and mortar. The sample was air-dried at room temperature and four hundred grams $(400 \mathrm{~g})$ of the pulverized and air-dried plant part was extracted by hot continuous, successive and exhaustive extraction using sohxlet apparatus. Petroleum ether, ethyl acetate, methanol and distilled water respectively were used (gradient extraction). The extracts were concentrated in vacuo, weighed and labeled petroleum ether (PEE), ethyl acetate $(\mathrm{EAE})$, methanol (MTE) and aqueous fractions (AQE) respectively, and stored aseptically in the refrigerator at $4{ }^{\circ} \mathrm{C}$ until use (Trease and Evans, 2002). All work was carried out in accordance with the general guidelines for methodologies on research and evaluation of traditional medicine (WHO, 2000; Geidam et al., 2007).

\section{Phytochemical analysis}

The various extracts of $C$. zambesicus were subjected to qualitative chemical screening for identification of the various classes of active chemical constituents (carbohydrates, tannins, phlobatannins, saponins, glycosides, terpenes/steroids, flavonoids, anthraquinones and alkaloids). The phytochemical analysis was done according to standard methods (Harbon, 1993; Sofowora, 1993; Trease and Evans, 2002).

\section{Preparation of microbial cultures}

Gram positive, gram negative and fungal laboratory isolates of Staphylococcus aureus, Streptococcus pyogenes, Shigella dysenteriae, Escherichia coli, Pseudomonas aerugenosa, Proteus vulgaris and Candida albicans were all obtained from human clinical cases at the University of Maiduguri Teaching Hospital (UMTH), Maiduguri, Nigeria. The isolates were propagated and stored on nutrient agar plate. The nutrient agar medium was obtained in dehydrated form (Oxoid Ltd. England) and was prepared according to the manufacturer's specification. All stock cultures were maintained on nutrient agar plate at $4^{\circ} \mathrm{C}$ and sub-cultured in nutrient broths (Oxoid Ltd. England) at $37^{\circ} \mathrm{C}$ for $8 \mathrm{~h}$ prior to antimicrobial testing. One milliliter of the cultures was then used to flood the agar plate.

\section{Preparation of stock solution of extracts}

Stock solutions of the extracts at $500 \mathrm{mg} / \mathrm{ml}$ each were prepared by dissolving $1 \mathrm{~g}$ of extracts into $2 \mathrm{ml}$ of diluents.

\section{Preparation of nutrient agar plate}

Nutrient agar was prepared according to the manufacturer's specification and $25 \mathrm{ml}$ of the agar was poured into sterile Petri dish. This was allowed to solidify and dry. Using a sterile cock-borer of 9 $\mathrm{mm}$ diameter, three equidistant holes (wells) per plate were made.

\section{Antimicrobial sensitivity testing}

The plate-hole diffusion method as described by Kudi et al. (1999), Ogundepe et al. (2000) and adopted by Reuben et al. (2008, $2009 a, 2009 b, 2009$ c) was used to determine the antibacterial activity of the extracts. One milliliter of the broth cultures were used to flood the agar plates. The three equidistant holes (wells) per plate were then filled with different extract solutions at concentrations of 500,400 and $300 \mathrm{mg} / \mathrm{ml}$ respectively. This was done in triplicates and the plates were then incubated at $37^{\circ} \mathrm{C}$ for $18 \mathrm{~h}$. The antibacterial activities were observed and the zone of growth inhibition measured using a transparent meter rule. Zones of inhibition $\geq$ $10 \mathrm{~mm}$ were recorded (Vlietink et al., 1995; Kudi et al., 1999; Geidam et al., 2007; Reuben et al., 2008, 2009a, 2009b, 2009c).

\section{Determination of minimum inhibitory concentration}

The minimum inhibitory concentration (MIC) of the extract fractions of $C$. zambesicus stem-bark were determined using the method adopted by Greenwood (1989), Vollekova et al. (2001), Dahiru et al. (2004), Usman et al. (2005, 2007), Geidam et al. (2007) and Reuben et al. (2008, 2009a, 2009b, 2009c). Ten sterile test tubes were arranged in six rows in a test tube rack, each row for one of the six microorganisms used for the test and $4 \mathrm{ml}$ of sterile nutrient broth was poured into all the tubes using pipette. In addition, $1 \mathrm{ml}$ of the stock extract solution at concentration of $500 \mathrm{mg} / \mathrm{ml}$ was diluted to $5 \mathrm{ml}$ to give concentration of $500 \mathrm{mg} / \mathrm{ml}$ and $4 \mathrm{ml}$ of these was dispensed into the first test tube containing $4 \mathrm{ml}$ of nutrient broth. This made concentration of $400 \mathrm{mg} / \mathrm{ml}$. Thereafter, there was a serial dilution of the extracts in each row to obtain concentrations of $200,100,50,25,12.5,6.25,3.13,1.56$ and $0.78 \mathrm{mg} / \mathrm{ml}$, respecttively. The test organisms $(0.2 \mathrm{ml})$ were put into each of the test tubes using a pipette and incubated at $37^{\circ} \mathrm{C}$ for $24 \mathrm{~h}$. Then MIC was determined and recorded as the lowest concentration of the extracts that completely inhibited the growth of the test organisms by showing no turbidity. The content of the tubes were further subcultured for $24 \mathrm{hrs}$ to determine minimum bactericidal concentration (MBC). This effect was demonstrated when no growth occurred on the sub-cultured medium after MIC determination.

\section{RESULTS}

Table 1 present the result of the form and color of the extracts of $C$. zambesicus. The result revealed higher yield of the methanol soluble fraction of the extracts 
Table 1. The yields of the various extracts of $C$. zambesicus Muell Arg. stem bark.

\begin{tabular}{lcccc}
\hline & \multicolumn{4}{c}{ Extracts } \\
\cline { 2 - 5 } & Petroleum ether & Ethylacetate & Methanol & Distilled water \\
\hline Color & Yellowish & Dark brown & Brown & Brown \\
Form & Oily paste & Mass & Mass & Mass \\
Extract weight $(\mathrm{g})$ & 17.197 & 50.56 & 52.023 & 26.4 \\
Yield w/w $(\%)$ & 4.30 & 12.64 & 13.01 & 6.6 \\
\hline
\end{tabular}

$52.023 \mathrm{~g}(13.01 \% \mathrm{w} / \mathrm{w})$ followed by ethyl acetate fraction $(50.563 \mathrm{~g}, 12.64 \% \mathrm{w} / \mathrm{w})$, the aqueous soluble fraction $(26.40 \mathrm{~g}, 6.60 \% \mathrm{w} / \mathrm{w})$ and petroleum ether fraction $(17.197 \mathrm{~g}, 4.30 \% \mathrm{w} / \mathrm{w})$. The result of the phytochemical screening of the various extract fractions of $C$. zambesicus is as presented in Table 2. The result revealed the presence of carbohydrates, cardiac glycosides, saponins, flavonoids, alkaloids, terpenoids and steroids.

The result of the in vitro antimicrobial sensitivity test is as presented in Table 3. The result shows that $S$. aureus, $S$. pyogenes, $E$. coli and $P$. aeruginosa are susceptible to various concentrations of petroleum ether; ethyl acetate and methanol extract fractions. S. dysenteriae showed susceptibility to the petroleum ether and methanol fractions but resistance to the ethyl acetate extract. $P$. vulgaris exhibited resistance to all the extracts while $C$. albican showed resistance to the petroleum ether fraction, but susceptibility to ethyl acetate and methanol fractions. All the test organisms exhibited resistance to the aqueous extract.

The result of the MIC test is as presented in Table 4. The least MIC value for petroleum ether extract was observed against $S$. dysenteriae, $S$. aureus and $E$. coli followed by $P$. aeruginosa and then $S$. pyogenes. The ethyl acetate extract showed least MIC for $P$. aeruginosa followed by $C$. albicans, $S$. pyogenes and $S$. aureus and finally $E$. coli. The methanolic extract exhibited the least MIC for $S$. aureus and E. coli followed by $P$. aeruginosa, the $S$. dysenterea and $C$. albicans, while $S$. pyogenes showed the least MIC value.

The result of the MBC test is presented in Table 5. The result revealed least $M B C$ value in petroleum ether extract against $S$. dysenteriae, S. aureus and E. coli, followed by $S$. pyogenes and $P$. aeruginosa. The ethyl acetate fraction showed least MBC against $P$. aeruginosa followed by $C$. albicans, then $S$. pyogenes and finally $S$. aureus and E. coli. The methanol extract fraction showed least MBC against $S$. aureus and $E$. coli followed by $P$. aeruginosa, then $S$. dysenterea and $C$. albicans and finally $S$. pyogenes.

\section{DISCUSSION}

The result of the phytochemical screening of the various extracts of $C$. zambesicus revealed the presence of carbohydrates, alkaloids, flavonoids, saponins, cardiac glycosides, terpenes and steroids. Phytochemicals are generally said to be non -nutritive plant chemicals that have protective or disease preventive properties. They are reported to protect the plants, but recent research demonstrates that they can protect humans against diseases. Some of the compounds that have been revealed in the plant under study, especially saponins, flavonoids, terpenes and steroids have been reported to have antibacterial/curative properties against several ailments whose causative agents are some of the organisms studied (Nweze et al., 2004; Hassan et al., 2004; Sartorato et al., 2004; Nwaogu et al., 2007; Usman et al., 2007) and so the activities observed in the present study is not unconnected with the presence of these phytochemicals. The in vitro antimicrobial assay of the extracts, which revealed various zones of inhibition of bacterial and fungal organisms indicate a broad spectrum antimicrobial property of the extracts.

The strength of the antibacterial efficacy of the extracts is expressed by the MIC and MBC respectively. Thus, the strongest activity for petroleum ether extract fraction was shown on S. dysenteriae, $S$. aureus and $E$. coli respectively with MIC of $25 \mathrm{mg} / \mathrm{ml}$ and MBC of $50 \mathrm{mg} / \mathrm{ml}$ while ethyl acetate extract had its own on $P$. aeruginosa with MIC of $3.125 \mathrm{mg}$ and MBC of $6.25 \mathrm{mg}$. The methanol extract fraction contains more strong bioactive constituents like the saponins, flavonoids, terpenes/ steroids all in moderate concentration. It therefore has its strongest activity on two bacterial species; one gram positive $S$. aureus and one gram negative $E$. coli with MIC and MBC value of $1.560 \mathrm{mg}$. All the others have MIC's and MBC' $\mathrm{s}$ above $12.5 \mathrm{mg}$ except for $P$. aeruginosa which have MIC and MBC value of $12.5 \mathrm{mg}$. The high activity observed of the methanol extract with as low MIC and MBC value of $1.56 \mathrm{mg}$ is not unconnected with the moderate presence of saponins, terpenes/steroids and flavonoids which have been associated with antimicrobial activity and in addition, the synergistic effect of these phytochemicals might also have contributed immensely to make the extract more active than the others, more so that saponin is absent in petroleum ether and ethyl acetate fractions (Erich, 1977; Hammer, 1999). It was also observed that the methanol extract have stronger antimicrobial activity, followed by 
Table 2. The results of phytochemical screening of extracts of Croton zambesicus Muell Arg. stem bark.

\begin{tabular}{|c|c|c|c|c|c|}
\hline $\mathbf{S} / \mathbf{N}$ & Constituents/test & $\begin{array}{c}\text { Pet. ether } \\
\text { extract }\end{array}$ & $\begin{array}{c}\text { Ethylacetete } \\
\text { extract }\end{array}$ & $\begin{array}{c}\text { Methanol } \\
\text { extract }\end{array}$ & $\begin{array}{c}\text { Aqueous } \\
\text { extract }\end{array}$ \\
\hline \multirow[t]{3}{*}{1.} & Alkaloids & & & & \\
\hline & i. Dragendorff's test & - & - & ++ & ++ \\
\hline & ii. Meyer's test & - & - & ++ & ++ \\
\hline \multirow[t]{5}{*}{2.} & Carbohydrates & & & & \\
\hline & i. Molisch' test & - & - & + & ++ \\
\hline & ii. Barford's test & - & - & - & - \\
\hline & iii. Fehling's test (reducing sugar test) & - & - & ++ & ++ \\
\hline & iv. Fehling's test (comb red. sugar test) & - & - & ++ & ++ \\
\hline \multirow[t]{2}{*}{3.} & Cardiac glycosides & & & & \\
\hline & Killer-Killani's test & - & - & + & ++ \\
\hline \multirow[t]{4}{*}{4.} & Flavonoids & & & & \\
\hline & i. Shinoda's test & - & + & - & ++ \\
\hline & ii. $\mathrm{FeCl}_{3}$ test & - & - & ++ & ++ \\
\hline & iii. Pew's test & - & - & ++ & ++ \\
\hline \multirow[t]{2}{*}{5.} & Saponins & & & & \\
\hline & Frothing test & - & - & ++ & ++ \\
\hline \multirow[t]{3}{*}{6.} & Steroidal nucleus (terpenes, steroids) & & & & \\
\hline & i. Salkwoski's test & ++ & ++ & ++ & + \\
\hline & ii. Liberman-Burchard's test & ++ & ++ & ++ & + \\
\hline \multirow[t]{3}{*}{7.} & Tannins & & & & \\
\hline & I. $\mathrm{FeCl}_{3}$ test & - & - & - & - \\
\hline & ii. Lead acetate test & - & - & - & - \\
\hline
\end{tabular}

- = negative (absent), + = positive (slightly present) $+++=$ positive (moderately present).

Table 3. The result of in vitro antimicrobial sensitivity testing of extracts of $C$. zambesicus Muell Arg. stem bark.

\begin{tabular}{|c|c|c|c|c|c|c|c|c|}
\hline & & Zones of inh & ition $(\mathrm{mm})(\mathrm{V}$ & \pm SEM) & & & & \\
\hline Extracts & Conc.(mg) & Sd & Sa & Sp & Ec & $\mathrm{Pa}$ & Pv & $\mathrm{Ca}$ \\
\hline \multirow[t]{4}{*}{ Petroleum ether } & 500 & $29.3 \pm 1.53$ & $20.0 \pm 1.00$ & $33.3 \pm 0.58$ & $24.3 \pm 1.15$ & $21.3 \pm 2.08$ & $\mathrm{R}$ & $\mathrm{R}$ \\
\hline & 400 & $25.3 \pm 0.58$ & $17.0 \pm 0.05$ & $30.0 \pm 0.00$ & $23.0 \pm 2.16$ & $19.0 \pm 1.73$ & $\mathrm{R}$ & $\mathrm{R}$ \\
\hline & 300 & $22.6 \pm 0.58$ & $15.2 \pm 0.29$ & $27.0 \pm 0.00$ & $19.7 \pm 0.58$ & $14.7 \pm 0.58$ & $\mathrm{R}$ & $\mathrm{R}$ \\
\hline & 500 & $\mathrm{R}$ & $20.3 \pm 0.58$ & $25.0 \pm 0.50$ & $31.0 \pm 1.00$ & $33.3 \pm 0.58$ & $\mathrm{R}$ & $18.2 \pm 0.29$ \\
\hline \multirow[t]{3}{*}{ Ethyl acetate } & 400 & $\mathrm{R}$ & $18.0 \pm 1.00$ & $22.0 \pm 0.00$ & $23.0 \pm 2.33$ & $31.3 \pm 1.15$ & $\mathrm{R}$ & $17.3 \pm 0.57$ \\
\hline & 300 & $\mathrm{R}$ & $15.0 \pm 0.29$ & $20.0 \pm 0.00$ & $20.0 \pm 0.00$ & $30.3 \pm 1.15$ & $\mathrm{R}$ & $15.5 \pm 0.58$ \\
\hline & 500 & $30.0 \pm 0.00$ & $30.0 \pm 0.00$ & $31.5 \pm 0.50$ & $30.0 \pm 0.00$ & $31.7 \pm 2.89$ & $\mathrm{R}$ & $30.0 \pm 0.00$ \\
\hline \multirow[t]{2}{*}{ Methanol } & 400 & $27.7 \pm 0.58$ & $30.0 \pm 0.00$ & $27.3 \pm 0.50$ & $28.3 \pm 1.53$ & $29.0 \pm 1.00$ & $R$ & $29.7 \pm 0.00$ \\
\hline & 300 & $25.0 \pm 0.00$ & $28.7 \pm 0.58$ & $23.0 \pm 0.00$ & $27.0 \pm 0.00$ & $26.7 \pm 2.89$ & $\mathrm{R}$ & $25.3 \pm 1.53$ \\
\hline \multirow{3}{*}{ Aqueous } & 500 & $\mathrm{R}$ & $\mathrm{R}$ & $\mathrm{R}$ & $\mathrm{R}$ & $\mathrm{R}$ & $\mathrm{R}$ & $\mathrm{R}$ \\
\hline & 400 & $R$ & $\mathrm{R}$ & $\mathrm{R}$ & $\mathrm{R}$ & $\mathrm{R}$ & $\mathrm{R}$ & $\mathrm{R}$ \\
\hline & 300 & $\mathrm{R}$ & $\mathrm{R}$ & $\mathrm{R}$ & $\mathrm{R}$ & $\mathrm{R}$ & $\mathrm{R}$ & $\mathrm{R}$ \\
\hline Tetracycline & 25 & 10 & 25 & 28 & 12 & 10 & NT & 13 \\
\hline
\end{tabular}

$\mathrm{Sd}=$ Shigella dysenterlae; $\mathrm{Sa}=$ Staphylococcus aureus; $\mathrm{Sp}=$ Streptococcus pyogenes; $\mathrm{Ec}=$ Escherichia coli; $\mathrm{Pa}=$ Pseudomonas aeruginosa; $\mathrm{Pv}$ $=$ Proteus vulgaris; $\mathrm{Ca}=$ Candida albicans, $\mathrm{R}=$ resistance $(+\mathrm{ve}) ; \mathrm{NT}=$ not tested; Control = tetracycline $25 \mathrm{mg}, \mathrm{n}=3$. 
Table 4. Minimum inhibitory concentration (MIC) of extracts $C$. zambesicus Muell Arg. stem bark against some microbial isolates.

\begin{tabular}{|c|c|c|c|c|c|c|c|c|c|c|}
\hline \multirow{2}{*}{ Extract } & \multirow{2}{*}{ Organism } & \multicolumn{9}{|c|}{ Extract conc. (mg/mL) } \\
\hline & & 0.780 & 1.560 & 3.125 & 6.25 & 12.5 & 25 & 50 & 100 & 200 \\
\hline \multirow{5}{*}{ Petroleum ether } & $\mathrm{Sd}$ & - & - & - & - & - & $\beta$ & + & + & + \\
\hline & $\mathrm{Sa}$ & - & - & - & - & - & $\beta$ & + & + & + \\
\hline & Sp & - & - & - & - & - & - & - & $\beta$ & + \\
\hline & Ec & - & - & - & - & - & $\beta$ & + & + & + \\
\hline & $\mathrm{Pa}$ & - & - & - & - & - & - & $\beta$ & + & + \\
\hline \multirow{5}{*}{ Ethyleacetate } & $\mathrm{Sa}$ & - & - & - & - & - & - & $\beta$ & + & + \\
\hline & $\mathrm{Sp}$ & - & - & - & - & - & $\beta$ & + & + & + \\
\hline & Ec & - & - & - & - & - & - & $\beta$ & + & + \\
\hline & $\mathrm{Pa}$ & - & - & $\beta$ & + & + & + & + & + & + \\
\hline & $\mathrm{Ca}$ & - & - & - & $\beta$ & + & + & + & + & + \\
\hline \multirow{6}{*}{ Methanol } & $\mathrm{Sd}$ & - & - & - & - & - & $\beta$ & + & + & + \\
\hline & $\mathrm{Sa}$ & - & $\beta$ & + & + & + & + & + & + & + \\
\hline & Sp & - & - & - & - & - & - & $\beta$ & + & + \\
\hline & Ec & - & $\beta$ & + & + & + & + & + & + & + \\
\hline & $\mathrm{Pa}$ & - & - & - & $\beta$ & + & + & + & + & + \\
\hline & $\mathrm{Ca}$ & - & - & - & - & - & $\beta$ & + & + & + \\
\hline
\end{tabular}

$\mathrm{Sd}=$ Shigella dysenterea; $\mathrm{Sa}=$ Staphilococcus aureus; $\mathrm{Sp}=$ Streptococcus pyogenes; $\mathrm{Ec}=$ Escherichia coli; $\mathrm{Pa}=$ Pseudomonas aerugenosa; $\mathrm{Ca}$ =Candida albicans. - = Resistance (growth of microbes/turbidity), $\beta=$ Minimum inhibitory concentration, that is, MIC (least extract concentrations that inhibit microbial growth/turbidity), + = Extract concentrations that inhibit microbial growth/turbidity.

Table 5. Minimum bactericidal/fungicidal concentration (MBC/MFC) of extract preparations of Croton zambesicus Muell Arg. Stem bark against some microbial isolates.

\begin{tabular}{|c|c|c|c|c|c|c|c|c|c|c|}
\hline \multirow[b]{2}{*}{ Extract } & \multirow{2}{*}{ Organism } & \multicolumn{9}{|c|}{ Extract conc. $(\mathrm{mg} / \mathrm{mL})$} \\
\hline & & 0.780 & 1.560 & 3.125 & 6.25 & 12.5 & 25 & 50 & 100 & 200 \\
\hline \multirow{5}{*}{ Petroleum ether } & Sd & - & - & - & - & - & - & $\beta$ & + & + \\
\hline & $\mathrm{Sa}$ & - & - & - & - & - & - & $\beta$ & + & + \\
\hline & Sp & - & - & - & - & - & - & - & $\beta$ & + \\
\hline & Ec & - & - & - & - & - & - & $\beta$ & + & + \\
\hline & $\mathrm{Pa}$ & - & - & - & - & - & - & - & $\beta$ & + \\
\hline \multirow{5}{*}{ Ethylacetate } & $\mathrm{Sa}$ & - & - & - & - & - & - & - & $\beta$ & + \\
\hline & Sp & - & - & - & - & - & - & $\beta$ & + & + \\
\hline & Ec & - & - & - & - & - & - & - & $\beta$ & + \\
\hline & $\mathrm{Pa}$ & - & - & - & $\beta$ & + & + & + & + & + \\
\hline & $\mathrm{Ca}$ & - & - & - & - & $\beta$ & + & + & + & + \\
\hline \multirow{6}{*}{ Methanol } & Sd & - & - & - & - & - & $\beta$ & + & + & + \\
\hline & $\mathrm{Sa}$ & - & $\beta$ & + & + & + & + & + & + & + \\
\hline & Sp & - & - & - & - & - & - & $\beta$ & + & + \\
\hline & Ec & - & $\beta$ & + & + & + & + & + & + & + \\
\hline & $\mathrm{Pa}$ & - & - & - & $\beta$ & + & + & + & + & + \\
\hline & $\mathrm{Ca}$ & - & - & - & - & - & $\beta$ & + & + & + \\
\hline
\end{tabular}

$\mathrm{Sd}=$ Shigella dysenterea; $\mathrm{Sa}=$ Staphylococcus aureus; $\mathrm{Sp}=$ Streptococcus pyogenes; Ec =Escherichia coli; Pa =Pseudomonas aeruginosa; $\mathrm{Ca}=$ Candida albicans, - = Resistance (growth of microbes/turbidity), $\beta=$ Minimum bactericidal/fungicidal concentration, that is, MBC/MFC (least extract concentration that kill bacteria/fungi). + = Extract concentrations that kill bacteria/fungi. 
ethyl acetate and petroleum ether fraction. The aqueous extract did not show any antimicrobial activity. The present study further substantiates earlier reports by Abbiw, (1990); Abo et al. (1999); Arbonnier et al. (2004) that the stem bark of $C$. zambesicus has antibacterial property and as well for its use in treatment of diarrhea and dysentery in folklore medicine.

\section{Conclusion}

The phytochemical analysis of $C$. zambesicus revealed the presence of pharmacologically active constituents which may explain the basis for the strong antimicrobial activity observed especially with the methanol fraction. The result of these studies has provided more basis and credence for the use of this plant in treatment of ailments whose causative agents are some of the pathogenic microbes used in this study, and thus suggest the possible usefulness of $C$. zambesicus in the treatment of bacterial and fungal infections. Finally, we suggest that further research work on the purification, characterization and structure elucidation of the constituents of the extracts be done with the view of getting the molecular and structural formula of the bioactive constituents as they may serve as novel compounds for the synthesis of new drugs with better therapeutic value.

\section{ACKNOWLEDGEMENT}

The efforts and assistance of Mr. Fine Akawu, Isa Gulani and Samson Gamache is highly appreciated.

\section{REFERENCES}

Abbew KD (1990). Useful plants of Ghana (West African uses of wild and cultivated plants). Inter. Tech. Pub. and Royal Botanical Gardens, England., 80(140): 152-237.

Abo KA, Ogunleye VO, Ashidi JS (1999). Antimicrobial potential of Spondias monben, Croton zambesicus and Zygotritonia crocea. Phytother. Res., 13: 494-497.

Agishi EC, Shehu Y (2004). Hausa, fulfulde and scientific names of plants. Agiata pub. Ltd., Makurdi., Nigeria. pp. 29- 115.

Adjanohoun EJ, Adjakidje V, De-Sauza S (1989). Contribution aux Estudes. Ethnobataniques. Floristiques en Republique populaire du Benin, vol. 1. Agence de cooperation cultunelle et. Technique. Paris, p. 245.

Ajoku GA, Ibrahim K, Enwerem N (2001). Antimicrobial activity of a Nigerian medicinal plant, Hibiscus sabdariffa. Nig. J. Biotechnol., 12: 82-85.

Akinniyi JA, Tella D (1991). Rural resources and national development (part 1): A case for the recognition of African traditional medicine in Nigeria. Anna. Borno., 6(7): 279-293.

Arbonnier M (2004). Trees, Shrubs and lianas of West African dry zones. CIRAD Margraf publishers GMBH. Germany, pp. 290-292.

Atawodi SE (2001). Antibacterial effects of Comberetum glutinosum, Tapinanth dodonnefolius on Salmonella gallinarum and Salmonella pullorum. Niger. J. Biotechnol., 12: 86-90.

Banso A, Olutimayin T (2001). Phytochemical and antimicrobial evaluation of aqueous extracts of Daniella oliveri and Nauclea latifolia. Niger. J. Biotechnol., pp. 114-118.
Chitme HR, Chandra R, Kaushik S (2003). Studies on anti-diarrheal activity of Calotropis giganta R. BR. In: Experimental Animals. J. Pharm. Sci., 7: 70-75.

Cordell GA (2000). Biodiversity and Drug discovery a symbiotic relationship. Phytochem., 55: 463-480.

Dahiru D, Ezeagwu SWC, William ET (2004). Antisalmonella activity of the extracts of Guira senegalensis and Zyzyphus mauritania on Salmonella gallinrium and Salmonella pullorum. Sahel J. Vet. Sci., 2: 7-9.

Enzo AP (2006). Phytochemicals from traditional medicinal plants used in the treatment of diarrhea: Modes of action and effects on intestinal function. Phytother. Res., 20: 717-724.

Erich H (1977). Functions of sterols in plants progress in phytochemistry, Harborne and Swain, Tokyo, pp. 257-273.

Geidam YA, Ambali AG, Onyeyili PA (2007). Phytochemical screening and antibacterial properties of organic solvent fractions of Psidium guajava aqueous extracts. Int. J. Pharmacol., 3: 68-73.

Greenwood D (1989). Antibiotic sensitivity testing. In: Antimicrobial chemotherapy (Greenwood, D. ed), Oxford University Press, New York. pp. 19-100.

Hammer KA, Carson CF, Riley TV (1999). Antimicrobial activity of essential oils and plant extracts. Appl. Microbiol., 86: 985.

Harborne JB (1993). Phytochemistry. Academic Press, London. pp. 1 226.

Hassan MM, Oyewale AO, Amupitan JO, Abdullahi MS and Okonkwo EM (2004). Preliminary phytochemical and antimicrobial investigation of crude extract of root bark of Deterium microcarpum. J. Chem. Sci. Niger., 29: 36-39.

Kim HS (2005). Do not put too much value on conventional medicine. J. Ethnopharmcol., 100: 37-39.

Kianbakht S Jahaniani F (2003). Evaluation of Antibacterial activity of Tribulus terrestris L. Growing in Iran. Iranian J. Pharmacol. Therap., 2: $22-24$.

Kudi AC, Umoh JU, Eduvic LO, Gefu J (1999). Screening of some Nigerian medicinal plants for antibacterial activity. J. Ethno. Pharm., 67: 225-228.

Nwaogu LA, Alisi C, Ibegbulem CO, Igwe CU (2007). Phytochemicl and antimicrobial activity of ethanolic extrac of Landolphia oweriensis leaf. Afr. J. Biotech., 6: 890-893.

Nweze El, Okafor JI, Njoku O (2004). Antimicrobial activities of methanolic extracts of Trame guinesis (Schum and thurn) and Morinda lucindu Benth used in Nigerian herbal medicinal practice. J. Bio. Res. Biotechnol., 2: 34-36.

Ogundepe OO, Moody JO, Fakeye TO, Ladip OB (2000). Antimicrobial activity of Mallotus oppositifolium extracts. Afr. J. Med. Sci., 29: 281 283.

Okokon JE, Ofodum KC, Ajibesin KK, Danladi B, Gamaniel KS (2005). Pharmacological screening and evaluation of anti-plasmodial activity of Croton zambesicus against Plasmodium berghei berghei infection in mice. Indian. J. Pharmacol., 35: 243-246.

Osuinde MI, Isibor ON (1998). In vitro antimicrobial activities of extracts of Spondias mombin L., Carica papaya L. and Viscum album L. J. Med. Lab. Sci., 7: 73-77.

Reuben KD, Abdulrahman FI, Akan JC, Usman H, Sodipo OA, Egwu GO (2008). Phytochemical screening and In vitro antimicrobial investigation of methanolic extract Croton zambesicus Muell. Arg. Stem bark. European J. Sci. Res., 23: 134-140.

Reuben KD, Abdulrahman FI, Akan JC, Egwu GO (2009a). Phytochemical composition and In vitro antimicrobial investigation of partition fractions of the crude methanolic extract of the stem bark of Croton zambesicus. J. Appl. Sci. Res., 5: 1014-1019.

Reuben KD, Abdulrahman FI, Akan JC, Sodipo OA (2009b). Phytochemical screening and antimicrobial studies of ethylacetate extract of Croton zambesicus Muell Arg. Stm bark. Pacific J. Sci. Tech., 10: 842-849.

Sartoratto A, Machado AIM, Delarmelina C, Figupira GM, Duarte MCT, Rehder VG (2004). Composition and antimicrobial activity of essential oils from aromatic plants used in Brazil. Brazilian J. Micro., 35: 275280

Sofowora A (1993). Screening plants for bioactive agents. In: Medicinal plants and traditional medicinal plants and traditional medicine in Africa. $2^{\text {nd. }}$ Ed. Spectrum Books Ltd. Sunshine House, Ibadan. pp. 
134-156.

Trease GE, Evans WC (2002). Pharmacognosy. $15^{\text {th }}$ ed. Saunders Pub. London. pp. 42-393.

Usman H, Osuji JC (2007). Phytochemical and In vitro antimicrobial assay of the leaf extract of Newbouldia laevis. Afr. J. Tcam., 4: 476480.

Usman H, Haruna AK, Akpulu IN, Iliyas M, Ahmadu AA, MusaYM (2005). Phytochemical and antimicrobial screenings of the leaf extracts of Celtis integration Lam. J. Trop. Biosci., 5: 72-76.
Usman H, Abdulrahman FI, Ladan AA (2007). Phytochemical and Antimicrobial evaluation of Tribulus terrestris L. (Zygophylaceae) growing in Nigeria. Res. J. of Bio. Sci., 2: 244-247.

Watt J, Mand Breyer-Brandwikj MG (1962). The medicinal and poisonous plants of southern and eastern Africa. $2^{\text {nd. }}$ edn. $E$ and $S$. Livingstone Ltd, London UK. 